\title{
Induction and Signaling of an Apoptotic Response Typified by DNA Laddering in the Defense Response of Oats to Infection and Elicitors
}

\author{
Yasuomi Tada, Shingo Hata, Yoko Takata, Hitoshi Nakayashiki, Yukio Tosa, and Shigeyuki Mayama \\ Graduate School of Natural Science and Technology, Kobe University, Kobe 657-8501, Japan \\ Accepted 11 December 2000.
}

Cells in the primary leaves of oats displayed internucleosomal DNA cleavage in response to incompatible crown rust infection. DNA laddering also was evident in leaves treated with calcium ionophore A23187, nonspecific elicitors such as chitin and chitosan oligomers, and victorin, which functions as a specific elicitor in $P c-2 / V b$ containing oat leaves. The nuclei in a victorin-treated susceptible oat line were positive for the TUNEL assay. These elicitors clearly induced a $28-\mathrm{kDa}$ nuclease (p28) in addition to three constitutive nucleases of 33, 24, and $22 \mathrm{kDa}$. Activation of p28 preceded the appearance of DNA laddering and possibly was mediated by de novo synthesis and/or cysteine protease activity. Pharmacological studies showed that the induction of DNA laddering was associated with oxidative stress, $\mathrm{Ca}^{2+}$ influx, and serine and cysteine proteases. Protein kinase and calmodulin activities did not seem to be involved in the induction of DNA laddering by victorin, whereas kinase-mediated signals were involved in DNA laddering induced by A23187. Protein kinase, calmodulin, G-protein activities, and $\mathrm{Ca}^{2+}$ influx, however, are involved in phytoalexin production. Our results imply that p28 is a possible nuclease candidate responsible for the induction of DNA laddering. The results also demonstrated that the mediators involved in the induction of apoptosis depended on the type of stimuli, whereas p28 and serine and cysteine proteases commonly are associated with each elicitor-induced apoptosis.

Apoptosis is a term used to designate an innate cell suicide mechanism in mammals that plays an important role in morphogenesis, metamorphosis, tissue homeostasis, and cellular defense reactions (Earnshaw 1995). Cells undergoing apoptosis display characteristic morphological changes that include shrinkage, chromatin condensation, and biochemical changes such as the cleavage of genomic DNA into internucleosomal 180-bp fragments, the latter of which often is referred to as "DNA laddering" (Earnshaw 1995; Wyllie 1980). Plant cells also exhibit programmed cell death, with similarities to apoptosis, in embryogenic morphogenesis (Fukuda et al. 1997; Wang et al 1996) and in response to various stresses, including fungal infection, toxins, and abiotic elicitors (Dangl et al.

Corresponding author: S. Mayama, Telephone: +81 78803 5864; Fax: +81 78803 5865; E-mail: mayama@kobe-u.ac.jp
1996; Gilchrist 1998; Greenberg et al. 1994; Navarre and Wolpert 1999; Pennell and Lamb 1997; Ryerson and Heath 1996; Wang et al. 1996).

In many plant-microbe interactions, recognition of an incompatible pathogen triggers the hypersensitive response (HR), resulting in rapid cell death accompanied by the activation of several defense-related genes (Mittler et al. 1997). Recent reports suggest that the HR, including elicitor induced, shares aspects of mammalian apoptotic processes such as nuclear condensation, activation of proteases, and DNA fragmentation (Dangl et al. 1996; Gilchrist 1998; Ryerson and Heath 1996; Solomon et al. 1999; Wang et al. 1996). It also has been reported that reactive oxygen species (ROS), proteases, calcium ion, and gene expression are involved in the commitment to apoptotic cell death in plants (Dangl et al. 1996; Gilchrist 1998; Greenberg et al. 1994; Levine et al. 1996; Pennell and Lamb 1997; Xu and Heath 1998). The mechanistic details in the execution of internucleosomal cleavage of chromosomal DNA and nuclear condensation, however, have not yet been fully elucidated.

The occurrence of DNA laddering is the biochemical phenomenon associated most commonly with apoptotic cell death (Wyllie 1980). Therefore, the detection of DNA laddering and identification and characterization of the endonucleases responsible for the DNA fragmentation are critical for understanding the molecular mechanisms of apoptosis in plants. Mittler and Lam (1995) reported that tobacco cell death during the HR is accompanied by an activation of several DNase. These endonucleases are involved in the degradation of DNA into approximately 50-kb fragments (Mittler and Lam 1995; Mittler and Lam 1997). In plants, however, it has not been reported that the activation of specific endonucleases is responsible for the internucleosomal degradation of chromosomal DNA.

We have been studying crown rust of oats, which clearly shows gene-for-gene-type resistance (Flor 1971) in the interactions between oat (Avena sativa L.) cultivars and races of crown rust fungus (Puccinia coronata f. sp. avenae) (Mayama et al. 1981; Mayama et al. 1982; Miyagawa et al. 1995). Genetic analysis showed that phytoalexin accumulation is linked closely to genes for resistance to crown rust fungus (Mayama et al. 1995a). Oat lines carrying the $P c-2 / V b$ gene are resistant to certain races of the crown rust pathogen, which is susceptible to Helminthosporium victoriae and sensitive to the hostspecific toxin victorin, which is produced by this fungus 
(Mayama et al. 1995b). Differential induction of phytoalexins by low concentrations of victorin in the $V b$ homozygous, homozygous recessive, and $F_{1}$ hybrid lines showed a gene dosage effect in response to victorin, confirming that victorin can function as a specific elicitor for the defense response in $P C$ $2 / \mathrm{Vb}$ oats (Mayama et al. 1986; Mayama et al. 1995b). The $\mathrm{Vb}$-victorin system is, therefore, a good model in which to study the active defense response of oats.

Chitosan, chitin-oligomers, and calcium ionophore A23187 are potent elicitors, whereas little elicitor activity is in oligogalacturonic acid, amino sugar monosaccharides, or glucan in oat leaves (Bordin et al. 1991; Ishihara et al. 1996). Tetramers to hexamers of chitooligosaccharides and $\mathrm{N}$-acetylchitooligosaccharides show remarkable activity in elicitation of phytoalexins (Mayama et al. 1996; Miyagawa et al. 1996). No elicitor activity was detected in the dimers to hexamers of laminarioligosaccharide, cellooligosaccharide, and isomaltooligosaccharide.

In this paper, we carry out a pharmacological study with oat leaves to dissect the cellular components aimed at their own self-execution induced by victorin and calcium ion. Additionally, we provide strong evidence that the activation of a nuclease is tightly associated with the induction of DNA laddering.

\section{RESULTS}

Apoptosis involvement in crown rust infection of oats.

The oat cultivar Shokan 1 is highly resistant to $P$. coronata f. sp. avenae race 226 and susceptible to race 203 . The production of oat phytoalexins (PAs) is involved in the incompatible race-cultivar interaction, resulting in resistance of oats to fungal infection (Mayama et al. 1981). DNA was extracted from the primary leaves of oats $36 \mathrm{~h}$ postinoculation. By this time, in the incompatible combination, haustorium-invaded mesophyll cells displayed a cessation of cytoplasmic streaming, a collapse of protoplasts, and the accumulation of PAs. DNA from leaves infected with race 226 showed laddering (Fig. 1). No laddering was observed at $36 \mathrm{~h}$ with DNA from the uninoculated leaves or leaves inoculated with the compatible race 203 (Fig. 1).

\section{Typical DNA laddering induction in oats by elicitors.}

Induction of DNA laddering was tested with the hostspecific toxin victorin that functions as a specific elicitor in victorin-sensitive oat lines. The excised leaves of the victorinsensitive cultivar Iowa X469 were treated with $5 \mathrm{ng}$ of victorin per $\mathrm{ml}$ for the indicated times. This toxin concentration was chosen because it led to the death of approximately $98 \%$ of the mesophyll cells of the exposed side of the peeled leaf segments after a 6-h treatment. DNA from the sensitive oat line showed DNA laddering $3 \mathrm{~h}$ after victorin treatment (Fig. 2A). Clear DNA laddering was detected $6 \mathrm{~h}$ after treatment, whereas no DNA laddering was observed with DNA from the toxin-treated, insensitive oat line Iowa X424 or with DNA from water-treated control leaves from both lines (data not shown). The effects of the oligosaccharide PA elicitors chitin and chitosan on DNA laddering in the primary leaves of cultivar Shokan 1 also were examined and compared with other oligosaccharides that do not show PA elicitor activity. Among the compounds tested, DNA laddering was clearly observed following a 12-h treatment with the PA elicitors 6DP-chitin (1 $\mathrm{mg}$ per $\mathrm{ml}$ ) and 6DP-chitosan (1 mg per ml) (Fig. 2B). Laminarin, cellulose, and isomaltose, which do not elicit PA accumulation, did not induce DNA laddering and were comparable to water-treated controls.

\section{Cytological confirmation of apoptotic response.}

In apoptotic cell death, DNA laddering often is accompanied by nuclear condensation (Earnshaw 1995; Gilchrist 1998; Liu et al. 1998). We carried out a cytological detection of DNA cleavage by TUNEL assays of nuclei in leaves treated with $5 \mathrm{ng}$ of victorin per $\mathrm{ml}$. TUNEL-positive nuclei were clearly observed in the victorin-treated mesophyll cells of victorin-sensitive leaves, but not in the water-treated control leaves (Fig. 3).

\section{Regulatory signals in induction of DNA laddering in victorin-treated oat leaves.}

Pharmacological studies were carried out to examine the regulatory signals controlling internucleosomal DNA cleavage detected in the victorin-treated, sensitive oat line Iowa X469. We confirmed that sole treatment of the inhibitors did not have any effect on DNA laddering and cell death in Iowa X469 (data not shown). We first tested whether DNA laddering could be influenced by chemical agents that affect $\mathrm{Ca}^{2+}$ metabolism such as ethylene glycol-bis[ $\beta$-aminoethyl ether]$N, N, N^{\prime}, N^{\prime}$-tetraacetic acid (EGTA), an extracellular $\mathrm{Ca}^{2+}$ chelator, EDTA (a divalent cation chelator), ruthenium red (an inhibitor of intracellular $\mathrm{Ca}^{2+}$ movement), nifedipine (a $\mathrm{Ca}^{2+}$ channel blocker), and $\mathrm{ZnCl}_{2}$ (a $\mathrm{Ca}^{2+}$ antagonist). The addition of these chemicals to test solutions prevented DNA-ladder formation induced by $5 \mathrm{ng}$ of victorin per $\mathrm{ml}$ (Fig. 4) and PA accumulation induced by $0.25 \mathrm{ng}$ of victorin per ml (Table 1 ).

The effects of calmodulin and G-protein inhibitors on PA accumulation and DNA laddering also were studied. The addition of the calmodulin antagonist trifluoperazine or the Gprotein inhibitor GDP- $\beta$-s to test solutions significantly inhib-

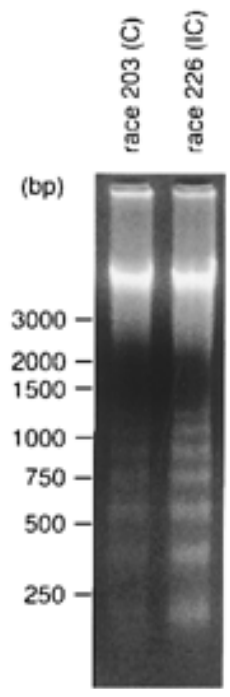

Fig. 1. Induction of DNA laddering in primary oat leaves by crown rust infection. Genomic DNA was extracted from leaves inoculated with the uredospores of Puccinia coronata f. sp. avenae, races 203 (C: compatible) and 226 (IC: incompatible) $36 \mathrm{~h}$ after inoculation and electrophoresed on a $2 \%$ agarose gel and stained by ethidium bromide. Size markers are shown on the left. 
ited victorin-induced PA induction (Table 1). No obvious effects on DNA fragmentation, however, were observed by these treatments (Fig. 5). To determine whether phosphorylation or protein synthesis were involved in victorin-induced DNA laddering, we tested the effects of K-252a (a serinethreonine kinase inhibitor), genistein (a tyrosine kinase inhibitor), okadaic acid (a serine-threonine phosphatase inhibitor), and cycloheximide (a eukaryotic protein synthesis inhibitor) on DNA laddering and PA induction. None of these inhibitors prevented the appearance of DNA laddering. The DNA bands from cycloheximide-treated tissues, however, were not as clear as those from the other treatments (Fig. 5). PA accumulation was blocked by simultaneous exposure of sensitive leaves (Iowa X469) to $0.25 \mathrm{ng}$ of victorin per $\mathrm{ml}$ as well as cycloheximide or K-252a. Okadaic acid, however, slightly elevated PA accumulation (Table 1).

The oxidative burst that evolves ROS such as $\mathrm{O}_{2}^{-}, \mathrm{H}_{2} \mathrm{O}_{2}$, and NO triggers a series of defense responses during hypersensitive cell death (Delledonne et al. 1998; Doke 1997; Durner et al. 1998; Levine et al. 1994; Noritake et al. 1996; Richberg et al. 1998). Thus, we tested the involvement of ROS on the induction of DNA laddering in victorin-treated, sensitive oat leaves. The addition of exogenous superoxide dismutase (SOD) and the cell-permeable ROS scavenger $\mathrm{N}$ acetyl-cysteine (NAC) could not suppress, but did delay, the formation of victorin-induced DNA laddering, as detected $6 \mathrm{~h}$ following treatment (Fig. 6). In contrast, the addition of the plasma membrane NADPH oxidase-NO synthase inhibitor diphenylene iodonium (DPI) did not inhibit but, rather, slightly exaggerated DNA laddering. As shown in Table 1, DPI significantly inhibited PA accumulation $24 \mathrm{~h}$ after treatment, whereas SOD suppressed PA induction by approximately $31 \%$ (Table 1). To investigate the possible involvement of NO in victorin-induced DNA laddering and PA production, we examined the effect of the NO synthase inhibitor $S, S^{\prime}-1,3-$ phenylene-bis (1,2-ethanediyl) bis-isothiourea (1,3-PBIT). This inhibitor markedly prevented PA accumulation, whereas DNA laddering was potentiated (Fig. 6 and Table 1).

In animals, the caspase family of cysteine proteases are activated in the execution of apoptosis, leading to DNA fragmentation (Enari et al. 1996; Liu et al. 1997). We studied whether a proteolytic event leading to DNA laddering was involved in the induction of oat cell death. Among the protease inhibitors tested, E-64 (a cysteine protease inhibitor) and aprotinin (a serine protease inhibitor) strongly attenuated the formation of victorin-induced DNA ladders in a dosedependent manner within $50 \mu \mathrm{M}$ to $1 \mathrm{mM}$ and 30 to $300 \mu \mathrm{g}$ per ml, respectively (Fig. 7). The aspartic acid protease inhibitor pepstatin A, however, did not have an effect on the DNA laddering within a concentration of 2 to $200 \mu \mathrm{M}$.

\section{Regulatory signals in induction of DNA laddering in A23187-treated oat leaves.}

Recent studies indicate that $\mathrm{Ca}^{2+}$ is involved in signaling leading to the HR during fungal infection or elicitor-induced resistance reactions (Gilchrist 1998; Levine et al. 1996; Xu

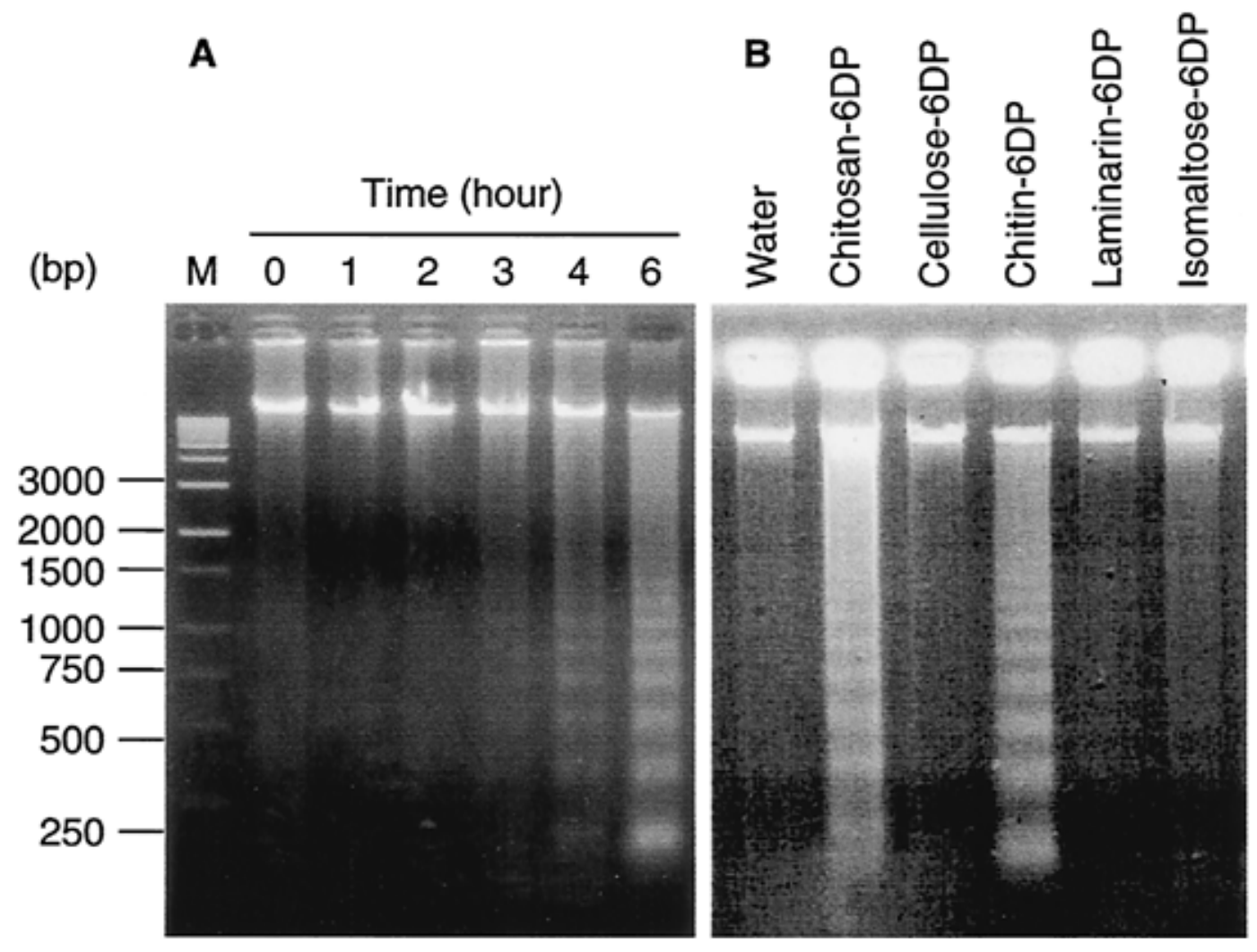

Fig. 2. Induction of DNA laddering by $\mathbf{A}$, victorin and $\mathbf{B}$, oligosaccharide elicitors in primary oat leaves. A, Epidermis-stripped leaf segments of oat cv. Iowa X469 were treated with $5 \mathrm{ng}$ of victorin C per ml for 1-6 h. B, Peeled leaf segments of oat cv. Shokan 1 were treated for $12 \mathrm{~h}$ with $1 \mathrm{mg}$ of chitin and chitosan oligomers per ml, which elicit PA production, and $1 \mathrm{mg}$ of cellooligosaccharides per ml, which do not elicit PA production. Genomic DNA was extracted from the treated leaves and electrophoresed as described in text. 
and Heath 1998). It has been shown that the calcium ionophore A23187 acts as an elicitor to activate the PA synthesis pathway in oats (Ishihara et al. 1996). We assessed the ability of $20 \mu \mathrm{M}$ A23187 treatment to induce DNA fragmentation in

Shokan 1 oat leaves. DNA laddering was clearly detectable $24 \mathrm{~h}$ after treatment. We then examined whether the cell death pathway activated by calcium was similar to that activated by treatment with $5 \mathrm{ng}$ of victorin per ml. In contrast to victorin treatment, calcium-induced DNA laddering could be suppressed by the kinase inhibitor K-252a and negated by the addition of exogenous SOD (Table 2). The addition of DPI and 1,3-PBIT, however increased the intensity of A23187induced DNA laddering much the same as with victorin treatment. Similar to what was found in victorin-treated leaves, E64 and aprotinin blocked the induction of DNA laddering in A23187-treated leaves, demonstrating the involvement of cysteine proteases and serine proteases in induction of DNA laddering (Table 2).

\section{Nucleases of oats and their induction signals.}

In apoptotic cell death, DNA fragmentation is often coincident with specific DNase activation (Aoyagi et al. 1998; Enari et al. 1998; Liu et al. 1997; Mittler and Lam 1995; Mittler and Lam 1997). The induction of nuclease activities was therefore examined in leaves treated with victorin or other elicitors. To visualize changes in the activity of DNases after individual treatments, we separated total protein by sodium dodecyl sulfate-polyacrylamide gel electrophoresis (SDS-PAGE) and used an in-gel DNase activity assay, as described below. A23187 and the elicitors chitin-6DP and chitosan-6DP clearly induced a putative nuclease of $28 \mathrm{kDa}(\mathrm{p} 28)$ after a $12-\mathrm{h}$ treatment (Fig. 8). Also observed were three additional, apparently constitutive DNases of 33, 24, and $22 \mathrm{kDa}$ (Fig. 8). The newly activated p28 DNase was not detected in leaves treated with elicitor-inactive oligosaccharides or water. The activation of p28 was detected as early as $1 \mathrm{~h}$ after treatment with $5 \mathrm{ng}$ of victorin per $\mathrm{ml}$ (Fig. 9A). Activation of p28 pre-

Table 1. Effects of inhibitors of cellular signal transduction pathways on PA accumulation and DNA laddering in primary leaves of cv. Iowa X469 treated with victorin

\begin{tabular}{|c|c|c|}
\hline Treatments $^{\mathrm{a}}$ & Avenanthramide $\mathbf{A}^{\mathbf{b}}$ & DNA laddering \\
\hline Water & $28.7 \pm 9.0$ & - \\
\hline Victorin & $1,220.0 \pm 103.9$ & + \\
\hline$+20 \mathrm{mM}$ EGTA & $11.9 \pm 3.1$ & - \\
\hline$+20 \mathrm{mM}$ EDTA & $96.3 \pm 56.2$ & - \\
\hline$+15 \mathrm{mM} \mathrm{ZnCl}_{2}$ & $170.5 \pm 32.4$ & - \\
\hline$+100 \mu \mathrm{M}$ ruthenium red & $16.6 \pm 2.0$ & - \\
\hline$+5 \mathrm{mM}$ nifedipine & $40.9 \pm 7.9$ & - \\
\hline$+5 \mu \mathrm{M} \mathrm{K}-252 \mathrm{a}$ & $11.8 \pm 5.7$ & + \\
\hline +500 nM okadaic acid & $2,109.8 \pm 348.7$ & + \\
\hline$+100 \mu \mathrm{M}$ GDP- $\beta-\mathrm{s}$ & $121.8 \pm 25.5$ & + \\
\hline$+750 \mu \mathrm{M}$ trifluoperazine & $7.4 \pm 0.5$ & + \\
\hline$+5 \mu \mathrm{M}$ cycloheximide & $30.0 \pm 2.1$ & + \\
\hline$+100 \mu \mathrm{g}$ of SOD per $\mathrm{ml}$ & $839.6 \pm 274.1$ & - \\
\hline$+1 \mathrm{mM} 1,3$-PBIT & $32.1 \pm 8.3$ & + \\
\hline$+100 \mu \mathrm{M}$ DPI & $33.8 \pm 3.6$ & + \\
\hline
\end{tabular}

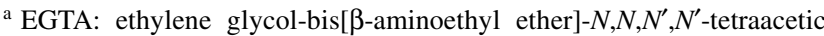
acid; SOD: superoxide dismutase; 1,3-PBIT S, $\mathrm{S}^{\prime}$-1,3-phenylene-bis (1,2-ethanediyl) bis-isothiourea; DPI: diphenylene iodonium.

b Avenanthramide A was estimated $24 \mathrm{~h}$ after treatment of $0.25 \mathrm{ng}$ of victorin per $\mathrm{ml}$. Data represent the mean \pm standard deviation from three experiments. Results at $\mu \mathrm{g}$ per $\mathrm{g}$ of fresh weight.

${ }^{c}$ DNA laddering detected $6 \mathrm{~h}$ after treatment of $5 \mathrm{ng}$ of victorin per $\mathrm{ml}$. ceded the appearance of internucleosomal cleavage of chromosomal DNA and was parallel with the percentage of dead cells (Fig. 9B and C). To characterize the p28 induction signal, we performed pharmacological tests in victorin-treated leaves with various inhibitors of signaling pathways. Calcium ions, de novo protein synthesis, and cysteine protease activity may be involved in p28 activation. Results indicated that serthr kinase and serine protease activities, however, were not involved in the newly induced nuclease activity (Fig. 10). Similarly, pepstatin A (an aspartic acid protease inhibitor) did not have a suppressive effect on p28 activity.

\section{DISCUSSION}

One prominent characteristic of apoptotic cells is the cleavage of DNA into fragments at sites separated by nucleosomes (Earnshaw 1995; Wyllie 1980). The present data clearly demonstrated that oats exhibited DNA laddering showing integer multiples of $180 \mathrm{bp}$ of DNA, identical with that of nucleosomes, in response to crown rust infection as well as various elicitors. The induction of DNA laddering was parallel with phytoalexin (PA) production in oat leaves in response to rust races and elicitors. Moreover, the formation of DNA ladders was a $\mathrm{Ca}^{2+}$-required active process, as was the PA induction, although both phenomena in the elicited responses were regulated through different signal transduction pathways. These data indicate that the cell death induced by any of the elicitors could not be necrosis, which is a passive form of cell death, and the defense response of primary oat leaves is asso-

A

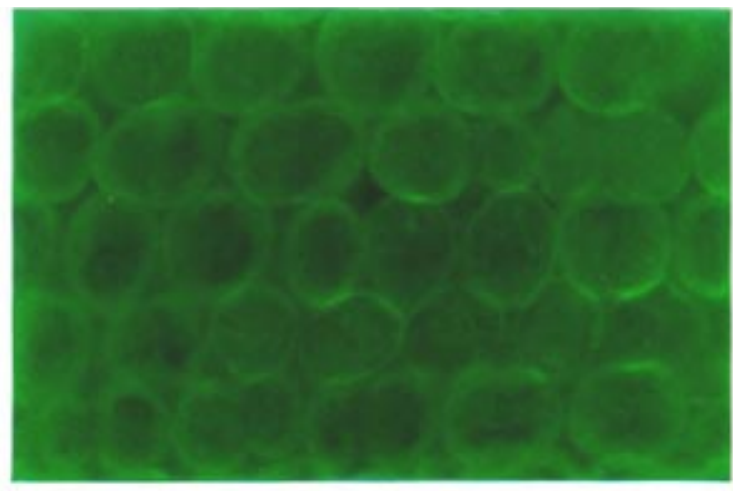

B

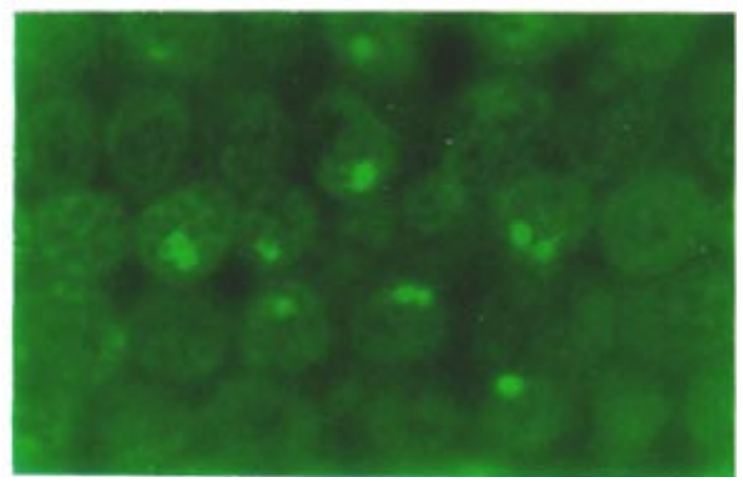

Fig. 3. Cytological detection of nuclear apoptosis in victorin-treated oat cv. Iowa X469 primary leaves. Peeled leaf segments of oat cv. Iowa $\mathrm{X} 469$ were floated with the exposed mesophyll side was in contact with A, water or B, $5 \mathrm{ng}$ of victorin C solution per $\mathrm{ml}$ for $6 \mathrm{~h}$. TUNEL assay was used to detect DNA fragmentation, and the exposed mesophyll sides were observed under a fluorescent microscope. 
ciated with the induction of an apoptosis-like cell death typified by internucleosomal DNA cleavage. Our recent study confirmed that immunogold labeling with an electron microscopy-TUNEL assay was detected extensively in the condensed chromatin as well as in the fragmented chromatin in the victorin-treated oat cells, as opposed to few labelings in the chemically induced necrotic cells (N. Yao et al. unpublished).

In mammals, a caspase-activated deoxyribonuclease (CAD) and its inhibitor (ICAD) have been identified in mouse lymphoma cells. CAD is produced as a complex with ICAD. Treatment with caspase-3 of cysteine protease releases the DNase, which causes DNA fragmentation (Enari et al. 1998). In plants, although random and ordered DNA degradation have been reported (Mittler and Lam 1995; Ryerson and Heath 1996; Wang et al. 1996), there is no clear evidence for a cell death-associated activation of a DNase leading to the internucleosomal degradation of chromosomal DNA. Here, we showed that p28 activation occurred as early as $1 \mathrm{~h}$ after treatment with $5 \mathrm{ng}$ of victorin per $\mathrm{ml}$ and preceded the ap-

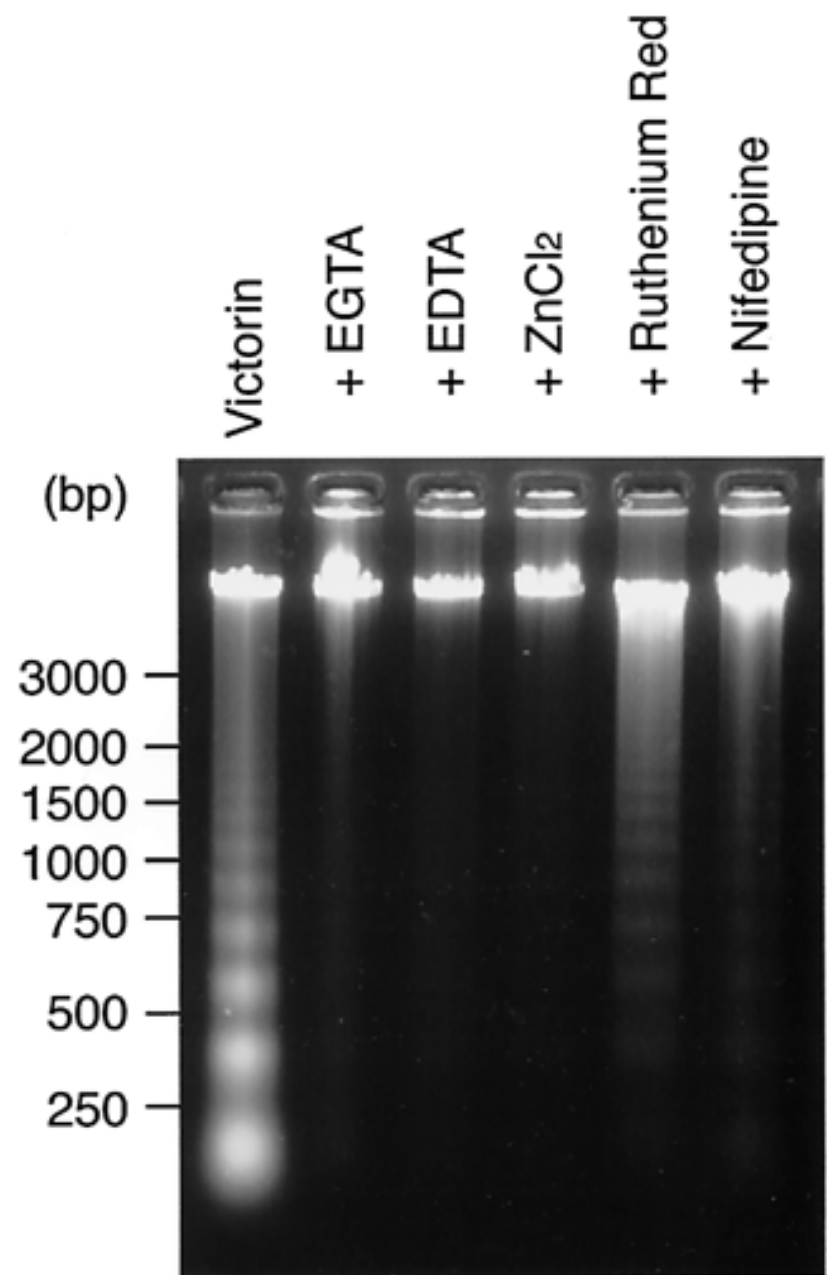

Fig. 4. Effects of calcium metabolism inhibitors on DNA laddering in oat cv. Iowa X469 treated with victorin. Peeled leaf segments were floated with the peeled side down on the solutions for $6 \mathrm{~h}$ at $20^{\circ} \mathrm{C}$. The following inhibitors of calcium metabolism were added to the $5 \mathrm{ng}$ of victorin solution per ml: $20 \mathrm{mM}$ EGTA as an extracellular $\mathrm{Ca}^{2+}$ chelator, $20 \mathrm{mM}$ EDTA as dication chelator, $15 \mathrm{mM} \mathrm{ZnCl}_{2}$ as a dication antagonist, $100 \mu \mathrm{M}$ ruthenium red as inhibitor of intracellular $\mathrm{Ca}^{2+}$ movement, and $5 \mathrm{mM}$ nifedipine as a $\mathrm{Ca}^{2+}$ channel blocker. pearance of DNA laddering. Relative p28 activation was paralleled with the amount of cell death. Therefore, we strongly suggest that p28 endonuclease is a candidate that is responsible for the induction of DNA laddering. Furthermore, the inhibition of cysteine protease activity resulted in the suppression of p28 activation and the formation of DNA ladders. It is therefore possible that a certain cysteine protease may be involved in the activation or induction of endonuclease p28 as well as in animal systems, which in turn leads to the degradation of DNA into nucleosomal fragments. As shown in Figure 9 , there is a possibility that the p28 nuclease is induced via a proteolytic cleavage of $\mathrm{p} 33$ nuclease. Although the serine protease inhibitor aprotinin suppressed DNA laddering, it had no effect on p28 activation. There also is a possibility, as in animal cells (Yoshida et al. 1996), that serine proteases are associated with the final step for induction of DNA fragmentation during apoptosis. In our current study, treatment with the protein synthesis inhibitor cycloheximide had a small effect on the induction of DNA laddering, whereas p28 activation was suppressed. This suggests the possibility that there is an active route through which p28 could induce nuclear apoptosis and an alternative pathway that is executed by constitutive nucleases such as p33 and p22.

In general, the apoptotic process is divided into two stages. The first is the induction phase, which depending on the type
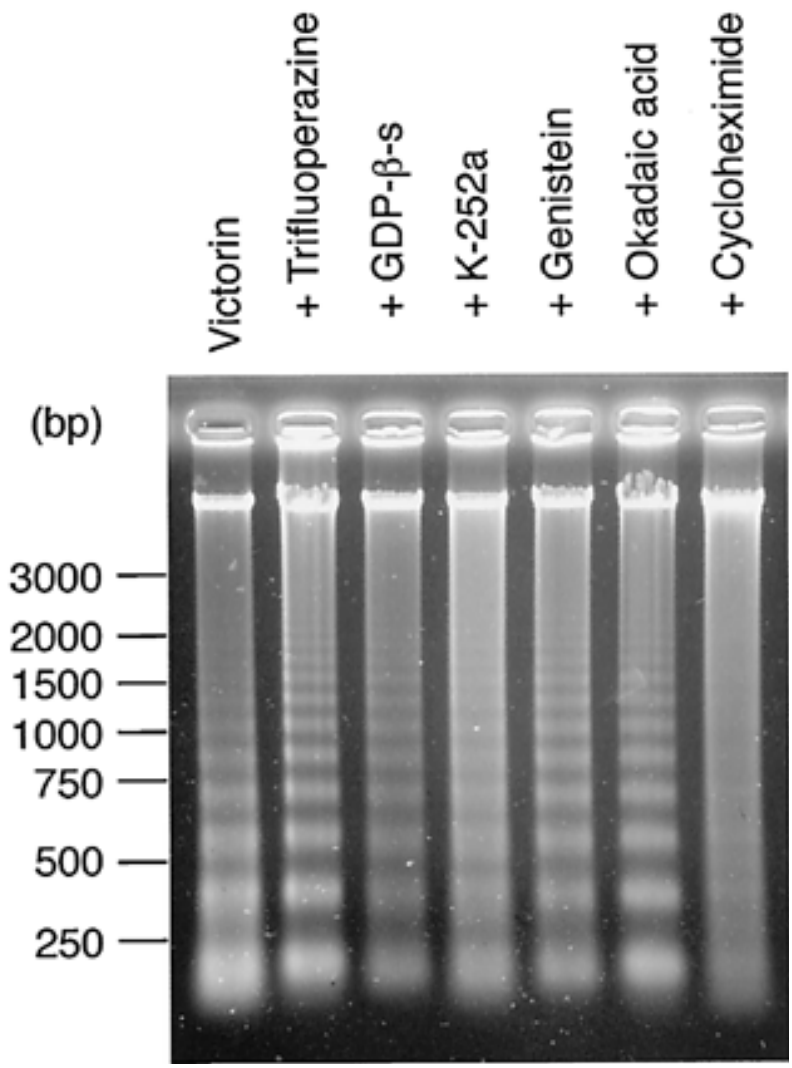

Fig. 5. Effects of signal transduction inhibitors on victorin-induced DNA laddering in oat cv. Iowa X469. Peeled leaf segments were floated with the peeled side down for $6 \mathrm{~h}$ at $20^{\circ} \mathrm{C}$ on solutions of $5 \mathrm{ng}$ of victorin per $\mathrm{ml}$ and victorin plus the inhibitors. Chemical concentrations were $750 \mu \mathrm{M}$ trifluoperazine, $100 \mu \mathrm{M}$ GDP- $\beta$-s, $5 \mu \mathrm{M}$ K-252a, $500 \mu \mathrm{M}$ genistein, $500 \mathrm{nM}$ okadaic acid, and $5 \mu \mathrm{M}$ cycloheximide. Genomic DNA was extracted and electrophoresed as described in text. 
of stimuli, leads to a commitment to apoptosis. The second is a common pathway, depending on the cell type, that participates in the degradation phase of apoptosis preceded by specific protease induction (Susin et al. 1997). Interestingly, each elicitor-active compound and host-specific toxin victorin could trigger the activation of p28 endonuclease and concomitantly induce DNA fragmentation, although they are deemed to stimulate a distinct signaling pathway. A high concentration of victorin has a lethal effect on $V b$-harboring cultivars by inhibiting the mitochondrial glycine decarboxylase multienzyme complex (Navarre and Wolpert 1995). The other elicitors such as chitin and chitosan, however, may induce cell death through the defense response. Therefore, it is likely that there is a common apoptotic machinery on which diverse signals derived from individual elicitors converges and that executes the degradation of oat cells. Our results show that the p28 nuclease and cysteine and serine proteases are involved in DNA-ladder formation associated with victorin- and calciuminduced cell death, although these cell deaths were induced through different pathways (Tables 1 and 2), suggesting that these enzymes participate in the common apoptotic degradation phase in oat cells. In animal cells, accumulating evidence shows that the disruption of mitochondrial transmembrane potential is an invariant feature of early apoptosis, independ-

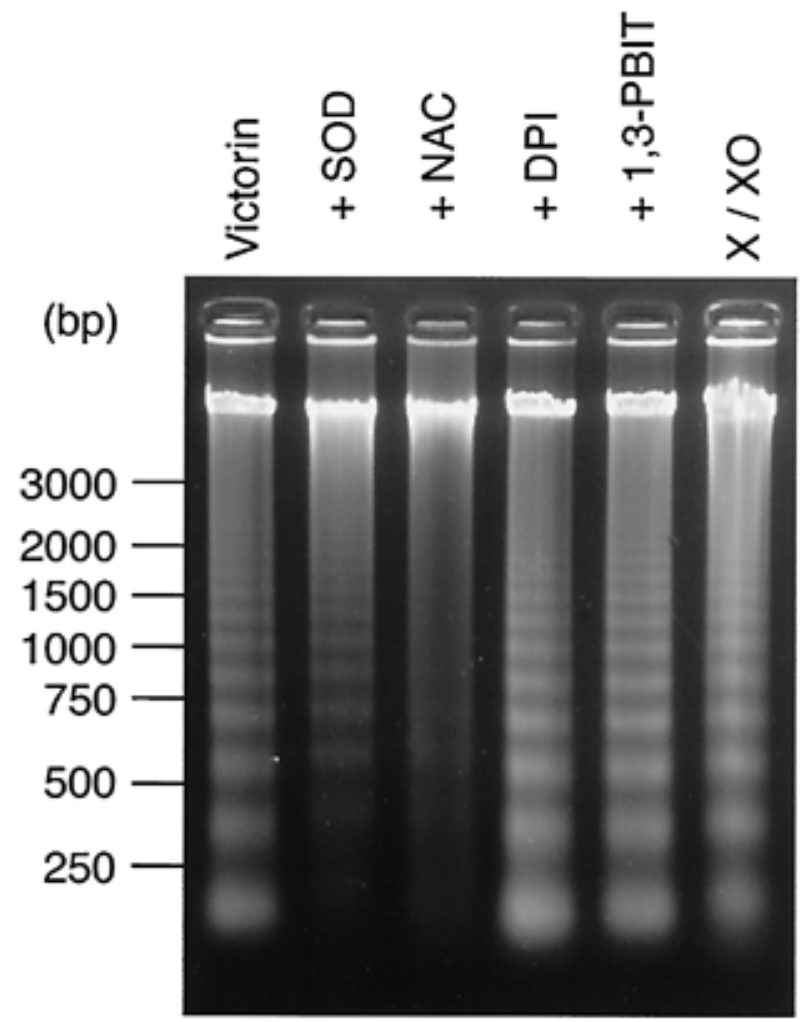

Fig. 6. Effects of the inhibition of the production and accumulation of reactive oxygen species on victorin-induced DNA laddering in oat cv. Iowa X469. Peeled leaf segments were floated with the peeled side down on $5 \mathrm{ng}$ of victorin per $\mathrm{ml}$ and victorin plus the indicated inhibitors for $6 \mathrm{~h}$ at $20^{\circ} \mathrm{C}$. Superoxide dismutase $(100 \mu \mathrm{g}$ per ml) and $2 \mathrm{mM} \mathrm{N}$ acetyl-cysteine as scavengers of reactive oxygen species, $100 \mu \mathrm{M}$ diphenylene iodonium as an inhibitor of NADPH oxidase-NO synthase and $1 \mathrm{mM} \mathrm{S}, \mathrm{S}^{\prime}$-1,3-phenylene-bis (1,2-ethanediyl) bis-isothiourea as an inhibitor of NO synthase, and xanthine-xanthine oxidase as a producer of $\mathrm{O}_{2}$ - was used as a treatment without victorin for $12 \mathrm{~h}$. ent from the cell type and the apoptosis-inducing stimulus (Castedo et al. 1995; Petit et al. 1995; Vayssiere et al. 1994; Zamzami et al. 1995). Further study is to be done to determine whether mitochondrial dysfunction will commit apoptosis-like cell death on another system.

It was recently demonstrated that D-ribulose-1,5-bisphosphate carboxylase-oxygenase (Rubisco) was proteolytically cleaved by cysteine proteases in victorin-treated susceptible oat tissue (Navarre and Wolpert 1999). Degradation of Rubisco is one of the hallmarks of plant senescence, and it may cause inhibition of the photorespiratory cycle. Although proteases should be involved in the degradation of various cellular substrates, including the activation of $\mathrm{p} 28$, one of the aspects by which protease inhibitors could attenuate victorin-induced DNA laddering may be a result of the inhibition of Rubisco degradation, which leads to fatal damage in oat cells (Navarre and Wolpert 1999).

\section{MATERIALS AND METHODS}

\section{Plant materials.}

Three cultivars of oats (Avena sativa L.) were used in this study. The oat cultivar Iowa X469 carrying the $V b$ gene is

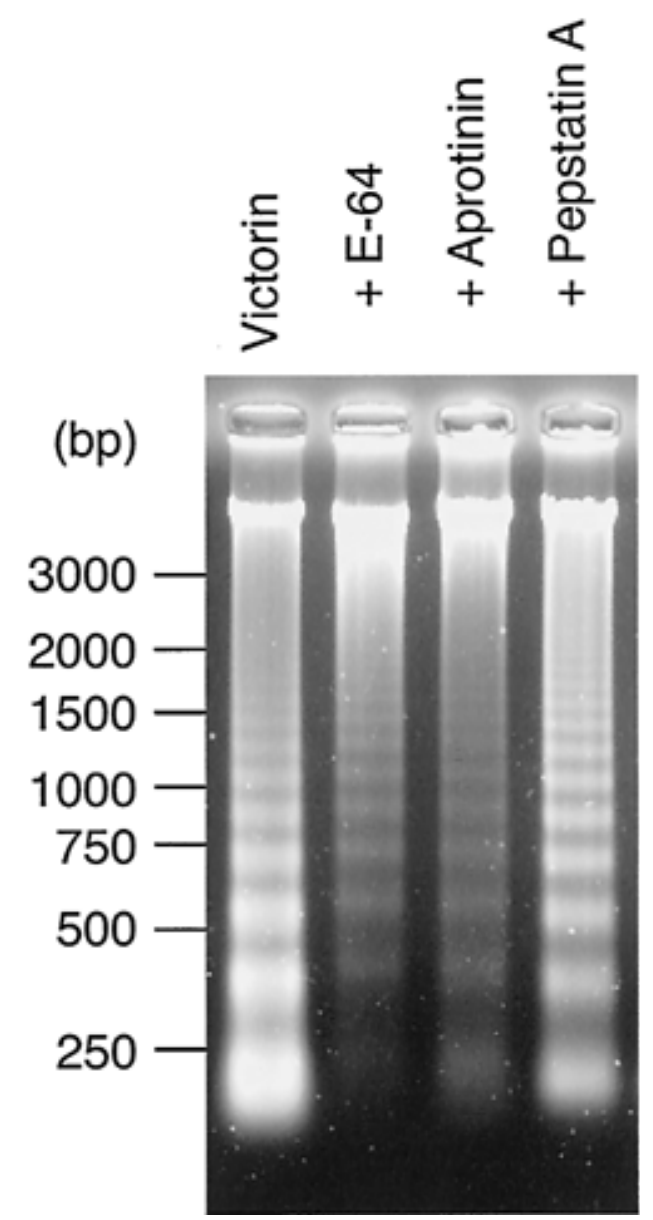

Fig. 7. Effects of protease inhibitors on victorin-induced DNA laddering in oat cv. Iowa X469. Peeled leaf segments were floated with the peeled side down on $5 \mathrm{ng}$ of victorin per $\mathrm{ml}$ and victorin plus the indicated inhibitors for $6 \mathrm{~h}$ at $20^{\circ} \mathrm{C}$. Chemical concentrations: $500 \mu \mathrm{M}$ E-64 as an inhibitor of cysteine protease, $150 \mu \mathrm{g}$ of aprotinin per $\mathrm{ml}$ as an inhibitor of serine protease, and $20 \mu \mathrm{M}$ pepstatin as an inhibitor of aspartic acid protease. Genomic DNA was extracted and electrophoresed as described in text. 
sensitive, whereas Iowa $\mathrm{X} 424$ is insensitive to the hostselective phytotoxin victorin $\mathrm{C}$ produced by $H$. victoriae. Shokan 1 is highly resistant to race 226 of the oat rust fungus and susceptible to race 203. Seeds of these cultivars were soaked in water for $2 \mathrm{~h}$, sown on vermiculite, and grown in a growth chamber at 20 to $21^{\circ} \mathrm{C}$ under illumination for $16 \mathrm{~h}$ daily with $10,000 \mathrm{~lx}$ fluorescent light. Seven- to 8 day-old primary leaves of oats were used for the present study.

\section{Production of inocula.}

Uredospores of the oat rust fungus ( $P$. coronata $\mathrm{f}$. sp. avenae) races 226 and 203 were produced on the susceptible host. Ten milligrams of uredospores mixed with $90 \mathrm{mg}$ of talc were sprinkled onto both surfaces of primary leaves. Inoculated seedlings were incubated in a humid chamber under dark for $16 \mathrm{~h}$ and transferred to the condition, as described above.

\section{Chitosan, chitin, and victorin $\mathrm{C}$ treatment.}

Hexamers of chitin, a linear $\beta(1-4)$-linked $N$-acetyl Dglucosamine, and those of chitosan, a deacetylated derivative of chitin, cellulose, laminarin, and isomaltose were obtained from Seikagaku kogyou (Tokyo, Japan). All oligosaccharides were used at the concentration of $1 \mathrm{mg}$ per $\mathrm{ml}$. The host specific toxin victorin $\mathrm{C}$ was provided by T. J. Wolpert (Oregon State University, U.S.A.). For the induction of PAs and DNA laddering, victorin was applied at a concentration of $0.25 \mathrm{ng}$ per $\mathrm{ml}$ for $24 \mathrm{~h}$ and $5.0 \mathrm{ng}$ per $\mathrm{ml}$ for $6 \mathrm{~h}$, respectively. The epidermis was peeled from the primary leaves and 5-cm segments were taken 1 to $6 \mathrm{~cm}$ from the leaf tip. Segments were floated on $3 \mathrm{ml}$ of test solution in $60 \times 15 \mathrm{~mm}$ petri dishes such that the peeled surface was in contact with the solutions. Incubations were conducted at $20^{\circ} \mathrm{C}$ under illumination.

\section{Chemicals.}

The inhibitors and their concentration used in the present study were 1 to $20 \mathrm{mM}$ EGTA as an extracellular $\mathrm{Ca}^{2+}$ chelator, 1 to $20 \mathrm{mM}$ EDTA as a divalent cation chelator, 1 to 15
$\mathrm{mM} \mathrm{ZnCl}{ }_{2}$ as a $\mathrm{Ca}^{2+}$ antagonist, 1 to $100 \mu \mathrm{M}$ ruthenium red as an inhibitor of intracellular $\mathrm{Ca}^{2+}$ movement, 0.5 to $5 \mathrm{mM}$ nifedipine as a $\mathrm{Ca}^{2+}$ channel blocker, 50 to $750 \mu \mathrm{M}$ trifluoperazine as a calmodulin antagonist, 1 to $100 \mu \mathrm{M}$ GDP- $\beta$-s as a G-protein inhibitor, 0.25 to $5 \mu \mathrm{M} \mathrm{K}-252 \mathrm{a}$ as a serinethreonine kinase inhibitor, 50 to $500 \mu \mathrm{M}$ genistein as a tyrosine kinase inhibitor, 5 to $500 \mathrm{nM}$ okadaic acid as a serinethreonine phosphatase inhibitor, 0.1 to $5 \mu \mathrm{M}$ cycloheximide as a de novo protein synthesis inhibitor, 10 to $200 \mu \mathrm{g}$ of SOD per $\mathrm{ml}, 0.1$ to $2 \mathrm{mM}$ NAC as a radical scavenger, 10 to $100 \mu \mathrm{M}$ DPI as a NADPH oxidase-NO synthase inhibitor, $50 \mu \mathrm{M}$ to 1 $\mathrm{mM} 1,3-\mathrm{PBIT}$ as a NO synthase inhibitor, 1 to $100 \mu \mathrm{M}$ xanthine-150 $\mathrm{mU}$ xanthine oxidase per $\mathrm{ml}$ as a superoxide generating system, $50 \mu \mathrm{M}$ to $1 \mathrm{mM}$ E-64 as a cysteine protease inhibitor, 30 to $300 \mu \mathrm{g}$ of aprotinin per $\mathrm{ml}$ as a serine protease inhibitor, 2 to $200 \mu \mathrm{M}$ pepstatin $\mathrm{A}$ as a aspartic protease inhibitor, and 10 to $20 \mu \mathrm{M}$ A23187 as an elicitor-active compound. The inhibitors were coincubated with victorin or A23187.

Table 2. Effects of inhibitors of cellular signal transduction pathways on DNA laddering and PA accumulation in primary leaves of cv. Shokan 1 treated with A23187

\begin{tabular}{lcc}
\hline Treatments $^{\mathbf{a}}$ & ${\text { Avenanthramide } \mathbf{A}^{\mathbf{b}}}^{\text {DNA laddering }}$ \\
\hline Water & $5.2 \pm 1.2$ & - \\
A23187 & $721.5 \pm 121.3$ & + \\
$+20 \mathrm{mM}$ EGTA & $11.9 \pm 3.1$ & - \\
$+5 \mu \mathrm{M} \mathrm{K}-252 \mathrm{a}$ & $18.8 \pm 6.5$ & - \\
$+100 \mu \mathrm{g}$ of SOD per ml & $526.5 \pm 98.5$ & - \\
$+1 \mathrm{mM}$ 1,3-PBIT & $56.9 \pm 19.0$ & + \\
$+500 \mu \mathrm{M}$ E-64 & Not determined & - \\
$+150 \mu \mathrm{g}$ aprotinin per ml & Not determined & - \\
$+20 \mu \mathrm{M}$ pepstatin A & Not determined & + \\
\hline
\end{tabular}

a EGTA: ethylene glycol-bis[ $\beta$-aminoethyl ether]- $N, N, N^{\prime}, N^{\prime}$-tetraacetic acid; SOD: superoxide dismutase; 1,3-PBIT S, $\mathrm{S}^{\prime}$-1,3-phenylene-bis (1,2-ethanediyl) bis-isothiourea; DPI: diphenylene iodonium.

b Avenanthramide A was estimated $24 \mathrm{~h}$ after treatment of $10 \mu \mathrm{M}$ A23187. Data represent the mean \pm standard deviation from three experiments. Results at $\mu \mathrm{g}$ per $\mathrm{g}$ fresh weight.

${ }^{c}$ DNA laddering was detected $12 \mathrm{~h}$ after treatment of $20 \mu \mathrm{M}$ A23187.

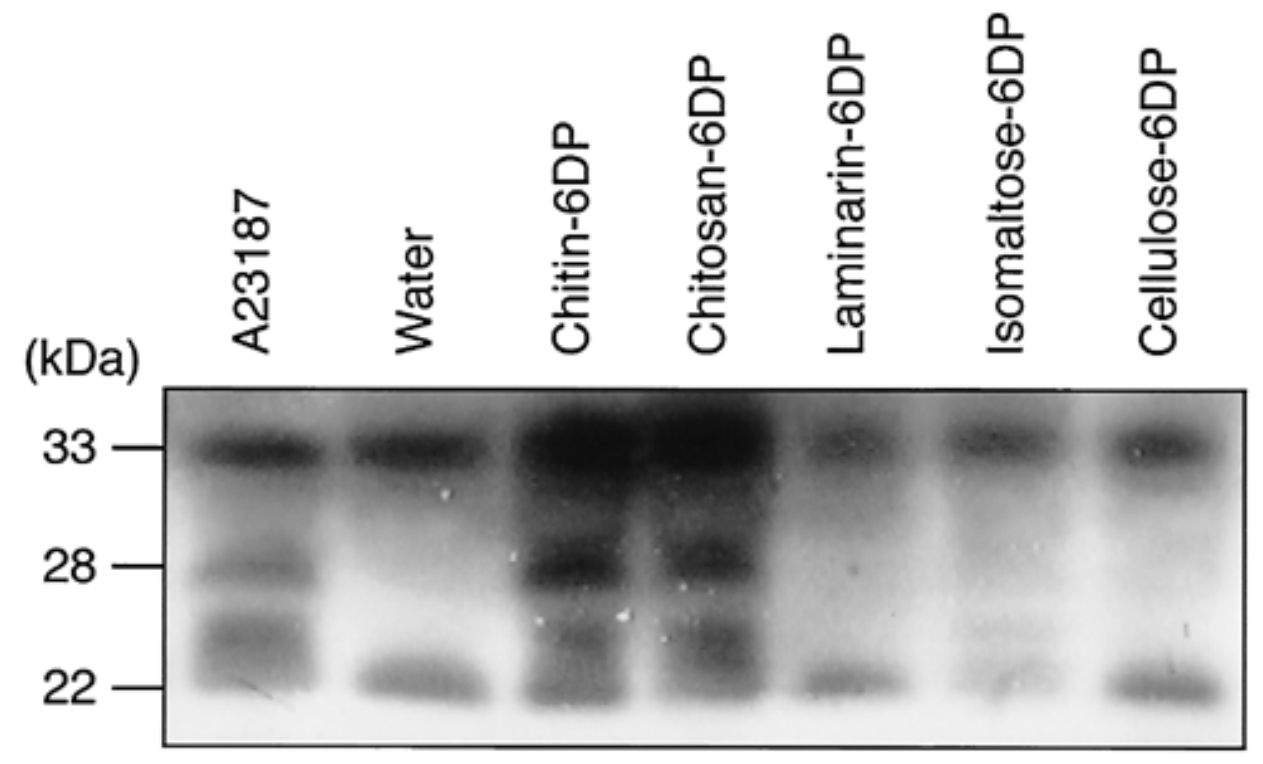

Fig. 8. Induction of the p28 endonuclease by the calcium ionophore A23187 or oligosaccharide elicitors. Peeled leaf segments of oat cv. Shokan 1 were floated with the peeled side down on solutions containing $20 \mu \mathrm{M}$ A23187, $1 \mathrm{mg}$ of chitin and chitosan oligomers per ml, and $1 \mathrm{mg}$ of cellooligosaccharides per $\mathrm{ml}$ for $12 \mathrm{~h}$. Cytosolic extracts were subjected to an in-gel nuclease assay as described in text. 
EGTA, EDTA, $\mathrm{ZnCl}_{2}$, ruthenium red, nifedipine, trifluoperazine, GDP- $\beta$-s, K-252a, genistein, cycloheximide, SOD, NAC, xanthine, xanthine oxidase, E-64, aprotinin, pepstatin A, and A23187 were obtained from Nacalai Tesque (Kyoto, Japan). Okadaic acid, DPI, and 1,3-PBIT were obtained from Sigma (Natick, MA, U.S.A.), Sigma-RBI (Natick, MA, U.S.A.), and Cayman Chemical (Ann Arbor, MI, U.S.A.), respectively.

\section{Cell mortality.}

Victorin-treated leaf segments were exposed to $2.5 \%$ Evans blue solution for $10 \mathrm{~min}$ at room temperature. After washing with distilled water, the dead cells were monitored by an Olympus (Tokyo, Japan) BH-2 fluorescence microscope.

\section{Detection of phytoalexin.}

Detection of avenanthramide A in the test solution was performed on a reversed-phase high-pressure liquid chromatography column (Hitachi gel no. 3056) eluted with $29 \%$ acetonitrile in distilled water containing $0.1 \%$ phosphoric acid. The quantity of avenanthramide A was estimated from UV absorbance at $340 \mathrm{~nm}$ with reference to a standard solution.

\section{TUNEL assay.}

Victorin-treated leaf segments were cut into small pieces and immediately fixed overnight at $4{ }^{\circ} \mathrm{C}$ in $4 \%$ paraformaldehyde with a $1 / 15 \mathrm{M}$ phosphate buffer, $\mathrm{pH}$ 7.4. The fluorescein ApopTag in situ apoptosis detection kit (Intergen, Purchase, NY, U.S.A.) was used to observe apoptotic mesophyll cells. The specimens were washed with PBS buffer $(50 \mathrm{mM}$ sodium phosphate and $200 \mathrm{mM} \mathrm{NaCl}, \mathrm{pH}$ 7.4) and equilibration buffer before the terminal deoxynucleotidyl transferase (TdT) was used. Tissue was treated with the mixture reagent containing $\mathrm{TdT}$ in a humidified chamber at $37^{\circ} \mathrm{C}$ for $1 \mathrm{~h}$ and stopped by adding stop-wash buffer. The specimens were then treated with an antidigoxigenin-fluorescein antibody conjugate and incubated for $45 \mathrm{~min}$ at room temperature. After washing three times with PBS, the specimens were observed with an Olympus $\mathrm{BH}-2$ fluorescence microscope with fluorescence filter.

\section{DNA extraction and analysis.}

Oat leaves $(0.3 \mathrm{~g})$ were frozen in liquid nitrogen and ground into a fine powder. Each sample was incubated for $30 \mathrm{~min}$ at $65^{\circ} \mathrm{C}$ in $600 \mu \mathrm{l}$ of $2 \%$ CTAB solution $(100 \mathrm{mM}$ Tris- $\mathrm{HCl}, \mathrm{pH}$ $8.0 ; 1.4 \mathrm{M} \mathrm{NaCl} ; 20 \mathrm{mM}$ EDTA; and $2 \%$ [wt/vol] cetyltrimethyl ammonium bromide), then mixed with an equal volume of chloroform-isoamyl alcohol (24:1). After gently shaking for $5 \mathrm{~min}$, the mixture was centrifuged for $15 \mathrm{~min}$ at 10,000 $\times$ $g$. The chloroform-isoamyl alcohol extraction was repeated when necessary. Total DNA was precipitated by the addition of $800 \mu \mathrm{l}$ of $1 \%$ CTAB solution $(50 \mathrm{mM}$ Tris- $\mathrm{HCl}, \mathrm{pH} 8.0 ; 10$ $\mathrm{mM}$ EDTA; and $1 \%$ [wt/vol] cetyltrimethyl ammonium bromide) to the supernatant. After centrifugation for $10 \mathrm{~min}$ at $8,000 \times g$, the pellet was dissolved in $400 \mu \mathrm{l}$ of $1 \mathrm{M} \mathrm{CsCl}$, and subjected to alcohol precipitation with a twofold volume of $100 \%$ ethanol. DNA was recovered by centrifugation for 10 min at $10,000 \times g$, followed by washing with $70 \%$ ethanol, and dissolved in $20 \mu \mathrm{l}$ of Tris-EDTA buffer containing $0.1 \mathrm{mg}$ of RNase per $\mathrm{ml}$. After incubation at $37^{\circ} \mathrm{C}$ for $30 \mathrm{~min}$, phenol extraction and ethanol precipitation were performed to recover the DNA. To detect DNA fragmentation, samples were run on a $2 \%(\mathrm{wt} / \mathrm{vol})$ agarose gel and stained with $0.5 \mu \mathrm{g}$ of ethidium bromide per $\mathrm{ml}$.

\section{Detection of nuclease activity.}

To identify DNase activity and estimate its molecular mass, the activity gel system for DNase was used with several modifications, as described previously (Shiokawa et al. 1997). Leaves $(1 \mathrm{~g})$ were ground to a fine powder in liquid nitrogen

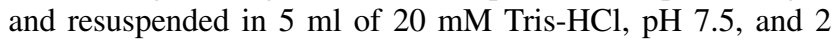
$\mathrm{mM}$ 2-mercaptoethanol. Protein was recovered from the supernatant following centrifugation for $15 \mathrm{~min}$ at $10,000 \times g$. The protein was electrophoresed in standard SDS-polyacrylamide gels containing $200 \mu \mathrm{g}$ of native calf thymus DNA per ml. After electrophoresis, the gels were washed with 10 $\mathrm{mM}$ Tris- $\mathrm{HCl}, \mathrm{pH} 7.8$, containing $5 \mathrm{mM}$ 2-mercaptoethanol at $50^{\circ} \mathrm{C}$ for $1 \mathrm{~h}$ to remove SDS and then with $10 \mathrm{mM}$ Tris- $\mathrm{HCl}$,

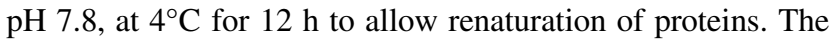
gels were incubated in $20 \mathrm{mM}$ morpholinepropanesulfonic
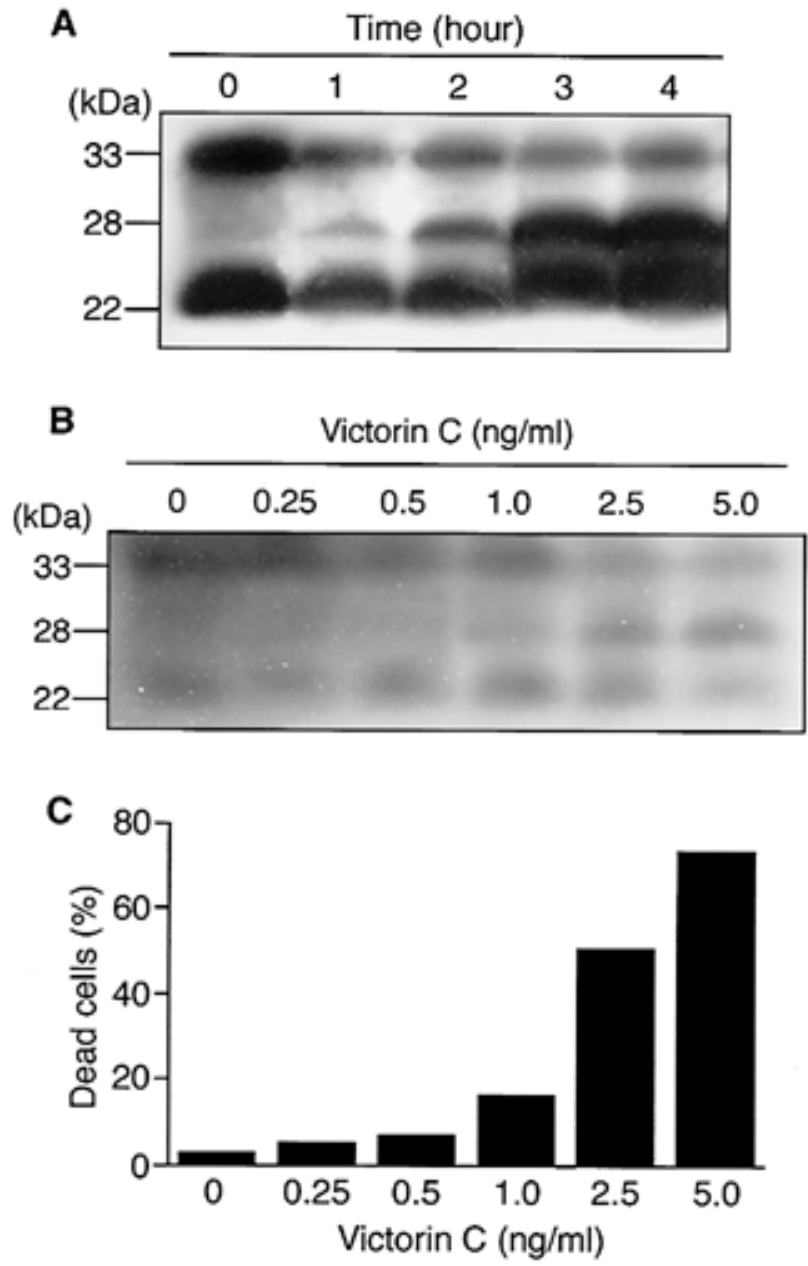

Fig. 9. Induction of the p 28 endonuclease by victorin in the primary leaves of Iowa X469. A, Time course of the induction of p28 nuclease activity. Peeled leaf segments were floated with the peeled side down on a solution of $5 \mathrm{ng}$ of victorin $\mathrm{C}$ per $\mathrm{ml}$ for $1-4 \mathrm{~h}$. B, Dose effect of victorin C on p28 nuclease induction. Peeled leaf segments were treated with victorin $\mathrm{C}$ for 4 $\mathrm{h}$ at the indicated concentration. Cytosolic extracts were subjected to an ingel nuclease assay as described in text. C, Percentage of dead cells in the treated leaves was estimated by Evans blue staining. 


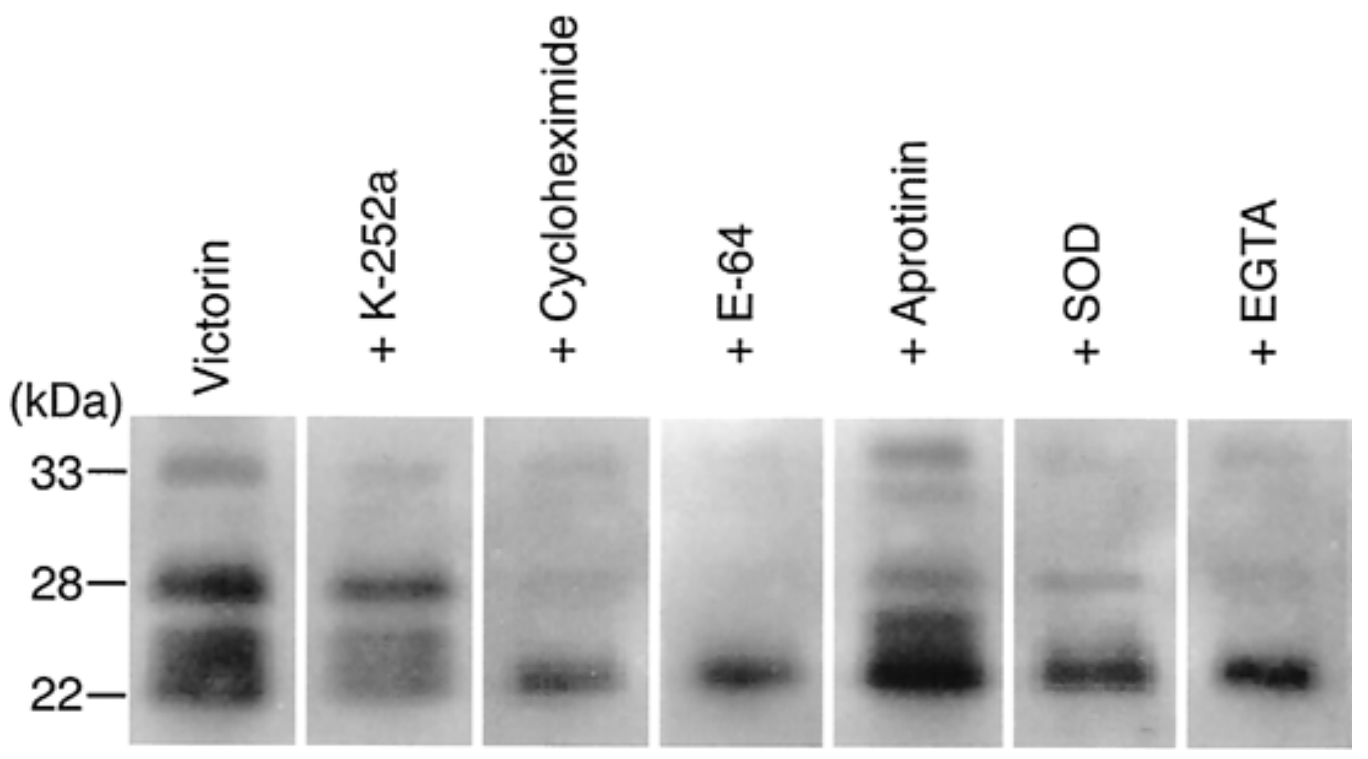

Fig. 10. Effects of signal transduction inhibitors on p 28 nuclease induction in victorin-treated primary leaves of Iowa X469. Peeled leaf segments were floated with the peeled side down on a solution of $5 \mathrm{ng}$ of victorin $\mathrm{C}$ per $\mathrm{ml}$ and victorin plus the inhibitors for $6 \mathrm{~h}$. Chemical concentrations: $5 \mu \mathrm{M}$ K-252a, $5 \mu \mathrm{M}$ cycloheximide, $500 \mu \mathrm{M} \mathrm{E}-64,150 \mu \mathrm{g}$ of aprotinin per ml, $100 \mu \mathrm{g}$ of superoxide dismutase per $\mathrm{ml}$, and $20 \mathrm{mM}$ ethylene glycol-bis[ $\beta$-aminoethyl ether]$N, N, N^{\prime}, N^{\prime}$-tetraacetic acid, an extracellular $\mathrm{Ca}^{2+}$ chelator. Cytosolic extracts were subjected to an in-gel nuclease assay as described in text.

acid- $\mathrm{KOH}$, $\mathrm{pH} 6.8$, containing $2 \mathrm{mM} \mathrm{CaCl}_{2}$ at $30^{\circ} \mathrm{C}$ for $20 \mathrm{~h}$ and in distilled water containing $0.5 \mu \mathrm{g}$ of ethidium bromide per $\mathrm{ml}$ for an additional $30 \mathrm{~min}$. Apparent nuclease activities were detected as dark areas on a fluorescent background after transillumination of the gels with UV light. The calibration curve constructed with molecular-mass standards was not affected by the presence of $200 \mu \mathrm{g}$ of DNA per $\mathrm{ml}$ in the SDSpolyacrylamide gels.

\section{ACKNOWLEDGMENTS}

We thank T. J. Wolpert for his critical reading of this manuscript. This work was supported in part by a Grant-in-Aid for Scientific Research (12052215) from the Ministry of Education, Science, Sports and Culture of Japan.

\section{LITERATURE CITED}

Aoyagi, S., Sugiyama, M., and Fukuda, H. 1998. BEN1 and ZEN1 cDNAs encoding S1-type DNases that are associated with programmed cell death in plants. FEBS Lett. 429:134-138.

Bordin, A. P. A., Mayama, S., and Tani, T. 1991. Potential elicitors for avenalumin accumulation in oat leaves. Ann. Phytopathol. Soc. Jpn. 57:688-695.

Castedo, M., Macho, A., Zamzami, N., Hirsch, T., Marchetti, P., Uriel, J., and Kroemer, G. 1995. Mitochondrial perturbations define lymphocytes undergoing apoptotic depletion in vivo. Eur. J. Immunol. 25:3277-3284

Dangl, J. L., Dietrich, R. A., and Richberg, M. H. 1996. Death don't have no mercy: Cell death programs in plant-microbe interactions. Plant Cell 8:1793-1807.

Delledonne, M., Xia, Y., Dixon, R. A., and Lamb, C. 1998. Nitric oxide functions as a signal in plant disease resistance. Nature 394:585-588.

Doke, N. 1997. The oxidative burst: Roles in signal transduction and plant stress. Pages 785-813 in: Oxidative Stress and the Molecular Biology of Antioxidant Defenses. J. G. Scandalios, ed. Cold Spring Harbor Laboratory, Cold Spring Harbor, NY, U.S.A.

Durner, J., Wendehenne, D., and Klessig, D. F. 1998. Defense gene induction in tobacco by nitric oxide, cyclic GMP, and cyclic ADPribose. Proc. Natl. Acad. Sci. USA 95:10328-10333.

Earnshaw, W. C. 1995. Nuclear changes in apoptosis. Curr. Biol. 7:337-
343.

Enari, M., Talanian, R. V., Wong, W. W., and Nagata, S. 1996. Sequential activation of ICE-like and CPP32-like proteases during Fasmediated apoptosis. Nature 380:723-726.

Enari, M., Sakahira, H., Yokoyama, H., Okawa, K., Iwamatsu, A., and Nagata, S. 1998. A caspase-activated DNase that degrades DNA during apoptosis, and its inhibitor ICAD. Nature 391:43-50.

Flor, H. 1971. Current status of the gene-for-gene concept. Annu. Rev. Phytopathol. 9:275-296.

Fukuda, H. 1997. Programmed cell death during vascular system formation. Cell Death Differ. 4:684-688.

Gilchrist, D. G. 1998. Programmed cell death in plant disease: The purpose and promise of cellular suicide. Ann. Rev. Phytopathol. 36:393414.

Greenberg, J. T., Guo, A., Klessig, D. F., and Ausubel, F. M. 1994. Programmed cell death in plants: A pathogen-triggered response activated coordinately with multiple defense functions. Cell 77:551-563.

Ishihara, A., Miyagawa, H., Kuwahara, Y., Ueno, T., and Mayama, S. 1996. Involvement of $\mathrm{Ca}^{2+}$ ion in phytoalexin induction in oats. Plant Sci. 115:9-16.

Levine, A., Tenhaken, R., Dixon, R., and Lamb, C. 1994. $\mathrm{H}_{2} \mathrm{O}_{2}$ from the oxidative burst orchestrates the plant hypersensitive disease resistance response. Cell 79:583-593.

Levine, A., Pennell, R. I., Alvarez, M. E., Palmer, R., and Lamb, C. 1996. Calcium-mediated apoptosis in a plant hypersensitive disease resistance response. Curr. Biol. 6:427-437.

Liu, X., Zou, H., Slaughter, C., and Wang, X. 1997. DFF, a heterodimeric protein that functions downstream of caspase-3 to trigger DNA fragmentation during apoptosis. Cell 89:175-184.

Liu, X., Li, P., Widlak, P., Zou, H., Luo, X., and Garrard, W. T. 1998. The 40-kDa subunit of DNA fragmentation factor induces DNA fragmentation and chromatin condensation during apoptosis. Proc. Natl. Acad. Sci. USA 95:8461-8466.

Mayama, S., Tani, T., and Matsuura, Y. 1981. The production of phytoalexins by oat in response to crown rust, Puccinia coronata f. sp. avenae. Physiol. Plant Pathol. 19:217-226.

Mayama, S., Matsuura, Y., Iida, H., and Tani, T. 1982. The role of avenalumin in the resistance of oat to crown rust, Puccinia coronata $\mathrm{f}$. sp. avenae. Physiol. Plant Pathol. 20:189-199.

Mayama, S., Tani, T., Ueno, T., Midland, S. L., Sims, J. J., and Keen, N. T. 1986. The purification of victorin and its phytoalexin elicitor activity in oat leaves. Physiol. Mol. Plant Pathol. 29:1-18.

Mayama, S., Bordin, A. P. A., Morikawa, T., Tanpo, H., and Kato, H. 1995a. Association between avenalumin accumulation, infection hy- 
pha length and infection type in oat crosses segregating for resistance to Puccinia coronata f. sp. avenae race 226. Physiol. Mol. Plant Pathol. 46:255-261.

Mayama, S., Bordin, A. P. A., Morikawa, T., Tanpo, H., and Kato, H. 1995b. Association of avenalumin accumulation with cosegregation of victorin sensitivity and crown rust resistance in oat lines carrying the Pc-2 gene. Physiol. Mol. Plant Pathol. 46:263-274.

Mayama, S., Ikegawa, T., Kobayashi, K. A., Zenbayashi, K., Nakayashiki, H., and Kato, H. 1996. Expression of specific resistance in crown rust-oat Interaction. Pages 221-231 in: Molecular Aspects of Pathogenicity and Resistance: Requirement for Signal Transduction. D. Mills, H. Kunoh, N. Keen, and S. Mayama, eds. American Phytopathological Society, St. Paul, MN, U.S.A.

Mittler, R., and Lam, E. 1995. Identification, characterization, and purification of a tobacco endonuclease activity induced upon hypersensitive response cell death. Plant Cell 7:1951-1962.

Mittler, R., and Lam, E. 1997. Characterization of nuclease activities and DNA fragmentation induced upon hypersensitive response cell death and mechanical stress. Plant Mol. Biol. 34:209-221.

Mittler, R., Pozo, O. D., Meisel, L., and Lam, E. 1997. Pathogeninduced programmed cell death in plants, a possible defense mechanism. Dev. Genet. 21:279-289.

Miyagawa, H., Ishihara, A., Nishimoto, T., Ueno, T., and Mayama, S. 1995. Induction of avenanthramides in oat leaves inoculated with crown rust fungus, Puccinia coronata f. sp. avenae. Biosci. Biotech. Biochem. 59:2305-2306.

Miyagawa, H., Ishihara, A., Kuwahara, Y., Ueno, T., and Mayama, S. 1996. Comparative studies of elicitors that induce phytoalexin in oats. J. Pestic. Sci. 21:203-207.

Navarre, D. A., and Wolpert, T. J. 1995. Inhibition of the glycine decarboxylase multienzyme complex by the host-selective toxin victorin. Plant Cell 7:463-471.

Navarre, D. A., and Wolpert, T. J. 1999. Victorin induction of an apoptosis/senescence-like response in oats. Plant Cell 11:237-249.

Noritake, T., Kawakita, K., and Doke, N. 1996. Nitric oxide induces phytoalexin accumulation in potato tuber tissue. Plant Cell Physiol. 37:113-116.

Pennell, R. I., and Lamb, C. 1997. Programmed cell death in plants. Plant Cell 9:1157-1168.

Petit, P. X., LeCoeur, H., Zorn, E., Dauguet, C., Mignotte, B., and
Gougeon, M. L. 1995. Alterations of mitochondrial structure and function are early events of dexamethasone-induced thymocytes apoptosis. J. Cell. Biol. 130:157-167.

Richberg, M. H., Aviv, D. H., and Dangl, J. 1998. Dead cells do tell tales. Curr. Opin. Plant Biol. 1:480-485.

Ryerson, D. E., and Heath, M. C. 1996. Cleavage of nuclear DNA into oligonucleosomal fragments during cell death induced by fungal infection or by abiotic treatments. Plant Cell 8:393-402.

Shiokawa, D., Ohyama, H., Yamada, T., and Tanuma, S. 1997. Purification and properties of DNase from apoptotic rat thymocytes. Biochem. J. 326:675-681.

Solomon, M., Belenghi, B., Delledonne, M., Menachem, E., and Levine, A. 1999. The involvement of cysteine proteases and protease inhibitor genes in the regulation of programmed cell death in plants. Plant Cell 11:431-443.

Susin, S. A., Zamzami, N., Castedo, M., Daugas, E., Wang, H. G., Geley, S., Fassy, F., Reed, J. C., and Kroemer, G. 1997. The central executioner of apoptosis: Multiple connections between protease activation and mitochondria in Fas/APO-1/CD95- and ceramide-induced apoptosis. J. Exp. Med. 186:25-37.

Vayssiere, J. L., Petit, P. X., Risler, Y., and Mignotte, B. 1994. Commitment to apoptosis is associated with changes in mitochondrial biogenesis and activity in cell lines conditionally immortalized with simian virus 40. Proc. Natl. Acad. Sci. USA 91:11752-11756.

Wang, H., Li, J., Bostock, R. M., and Gilchrist, D. G. 1996. Apoptosis: A functional paradigm for programmed plant cell death induced by a host-selective phytotoxin and invoked during development. Plant Cell 8:375-391.

Wyllie, A. H. 1980. Glucocorticoid-induced thymocyte apoptosis is associated with endogenous endonuclease activation. Nature 284:555-556.

Xu, H., and Heath, M. C. 1998. Role of calcium in signal transduction during the hypersensitive response caused by basidiospore-derived infection of the cowpea rust fungus. Plant Cell 10:585-597.

Yoshida, A., Takauji, R., Inuzawa, M., Ueda, T., and Nakamura, T. 1996. Role of serine and ICE-like proteases in induction of apoptosis by etoposide in human leukemia HL-60 cells. Leukemia 10:821-824.

Zamzami, N., Marchetti, P., Castedo, M., Zanin, C., Vayssiere, J. L., Petit, P. X., and Kromer, G. 1995. Reduction in mitochondrial potential constitutes an early irreversible step of programmed lymphocyte death in vivo. J. Exp. Med. 181:1661-1672. 